\title{
Do Foreign Firms in China Incur a Liability of Foreignness? The Local Chinese Firms' Perspective
}

\author{
Fuming Jiang* \\ Curtin Business School, Curtin University \\ Fuming.jiang@curtin.edu.au
}

Lixian Liu

School of Information Systems and Accounting, University of Canberra

Lixian.liu@canberra.edu.au

Bruce W. Stening

National School of Development, Peking University

Bruce.stening@bimba.pku.edu.cn

\begin{abstract}
Liability of foreignness has been one of the building blocks of multinational enterprise theory development, but we have limited knowledge about the liability of foreignness in the context of multinationals operating in developing countries. This study suggests that in a developing country like China, foreignness may still exist, but its negative impact on foreign firms' performance may have become insignificant. Local Chinese firms were found to enjoy significant location-based advantages over their foreign counterparts, contributing to liability of foreignness. However, the adverse effects of liability of foreignness on foreign firms appear to be off-set by the foreign firms' superior firm-specific and multinationality advantages over local Chinese firms. Further, the location-based advantages that foreign firms have built up over time further serve to strength their overall competitive position in China.
\end{abstract}

Keywords: Liability of foreignness, emerging markets, China, foreign firms, local firms.

* Correspondence author 


\section{Introduction}

Hymer (1960/1970) pioneered the study of the liability of foreignness (LOF) related to multinational enterprise theories. He asserted that firms operating abroad confront significant challenges and incur additional costs relative to their local indigenous counterparts. A number of influential studies (e.g., Mezias, 2002; Miller \& Parkhe, 2002; Zaheer, 1995; Zaheer \& Mosakowski, 1997) have recently re-examined these issues. These studies generally confirmed that such a liability still exists and that the LOF-based competitive disadvantage adversely affects foreign firms’ performance in foreign markets. However, neither Nachum (2003) nor Kronborg and Thomsen (2009) were able to confirm the existence of an LOF. Nachum (2010) has also questioned the conventional wisdom of the LOF, arguing that foreignness may be either an asset or a liability depending on the circumstances. In this paper, we argue that in a developing country such as China, foreignness may still exist for the developed country firms operating in the developing country. However, the negative impact of foreignness on the foreign firms' performance may become insignificant due to the superior resource-based competitive advantages that the foreign firms possess, such as firm-specific and multinationality advantages. Assumptions are often made about the presence of an LOF in China. However, while some research has been done into related phenomena, such as Chang and Xu's (2008) work on spillovers and competition among foreign and local firms, no empirical data has yet been collected that specifically investigates the LOF in China. Furthermore, the assumptions made about the LOF are embedded in views about China that are, in many instances, outdated. The LOF is not static; it changes as both a firm's external environment and its internal capacities and resources develop over time (Zaheer \& Mosakowski, 1997).

Since the Chinese government's decision regarding "reform and opening up" in 1978, the central government has taken a gradual, experimental, and pragmatic approach, described as 'crossing the river by touching stones,' to reform the state-owned enterprises (SOEs) (Chartier, 1998; Xu, 2011). This process has contributed to the emergence of China's state capitalism. China's state capitalism has strong governments to direct investment and suppress labor (Fligstein \& Zhang, 2011). In the late 1990s, China tried to form SOEs into big business groups similar to those in Japan and Korea (White, Hoskisson, Yiu, \& Bruton, 2008). The Chinese state freely creates and maintains enterprises, holds a majority of the shareholdings, controls critical personnel decisions, and supplies capital (Haley, Haley, \& Tan, 2004; Lin, 2011); these 
characteristics signify the unique characteristics of China's state capitalism. State capitalism varies across two dimensions - the extent of the state's ownership of production and the extent of the state's coordination with other enterprises. Among nation-states, China uniquely synchronizes the party, the government, the military, and the economy (Lin, 2011), and China's state capitalism is represented by strong governments that direct investment and suppress labor (Fligstein \& Zhang, 2011). Therefore, the state controls firms in the core Chinese economy while SOEs compete with other enterprises, including foreign investment enterprises in the country and internationally.

In the last three decades, China has undergone tremendous changes in relation to its foreign investment policies and practices, many of which have favored foreign investors (Elliot, Jiang, Redding \& Stening, 2010). The legal framework for foreign investment, for instance, has gone from a virtual void to one of the most complete legal systems in any transitional economy, and the economy has gradually been converted from a centrally planned economy to a market system (Walder, 1996; Jiang, 2005), albeit with Chinese characteristics (Huang, 2008). In recent years, the regulatory treatment of foreign and local firms has progressively converged, and many entry and operational barriers to foreign direct investment (FDI) have been removed or significantly reduced. Some industries that were previously closed to foreign investors, especially in the service sector, such as retailing, insurance, and banking, have now been opened (Luo, 2007), largely as a consequence of China's admission to the World Trade Organization in 2001. This type of market liberalization can be expected to decrease the negative effect of the LOF (Nachum, 2003; Zaheer \& Mosakowski, 1997).

In addition, foreign firms have been progressively and effectively developing their China location-based advantages such as guanxi networks (Tsang, 1998). This development is reflected by the increased level of resources committed to their China-based operations (for example, the increased total assets of foreign affiliates, the number and value of mergers and acquisitions by foreign affiliates, and the level of research and development (R\&D) of foreign firms) and the impressive performance of foreign firms in China in recent years (UNCTAD, 2005-2010). The theory of incremental international expansion relates FDI motives to the accumulation of international experience and the reduction of location-based disadvantages. Similarly, the level of a foreign firm's pool of local knowledge and operational experience is positively related to the level of its resource commitment in FDI (Johanson \& Vahlne, 1977). We therefore argue that the 
dramatic improvement in the overall business environment in China over the past three decades, together with the accumulation of foreign firms' knowledge of China and their operational experience in China, may have significantly reduced the cost of doing business there. Accordingly, our key research questions are as follows: Do foreign firms (still) incur additional costs for doing business in China relative to Chinese firms? And, if so, do such additional costs have a significant adverse impact on the foreign firms' performance in China? While most studies of international competition are undertaken from the perspective of foreign firms, it is just as important to examine local firms (Jiang \& Stening, 2013). How local firms view the nature of international competition — especially issues related to the LOF-may be of strategic importance to all of the players in the game and to their competitive positions in this 'playing field'.

\section{Theory and Hypotheses}

Studies of the advantages held by multinational corporations (MNCs) implicitly and/or explicitly identify and distinguish between several aspects of competitive advantage, including firmspecific advantages (FSAs) arising from the possession of certain intangible capabilities; multinationality advantages (MNAs) associated with multinational activity per se; and home- or localbased advantages (LBAs) arising from the exclusive access of firms to resources and conditions in their home countries (Dunning, 1981; Nachum, 2003). These advantages together form the competitiveness of firms in global markets, and the strength of these advantages can determine the relative competitive position of foreign MNCs and local firms (Nachum, 2003). Therefore, the existence, strength, and extent of the LOF in China will depend on the relative strength of each of these advantages possessed by foreign and local firms. We propose that the liability of foreignness, as measured by the relative performance of foreign firms compared to local Chinese firms (Nachum, 2003), is represented by the aggregated outcomes of various competitive advantages that are possessed by the players from each side when competing in the same (China) market, consequently determining the strength of the LOF. We incorporated six independent variable constructs into our conceptual framework (see FIGURE 1) to capture the joint impact of the three types of advantage that both local and foreign firms may possess.

INSERT FIGURE 1 ABOUT HERE 


\section{Firm-Specific Advantages}

Firm-specific advantages are the necessary condition for foreign activities (Hymer (1960/1976). These advantages stem from the proprietary assets of MNCs that arise from their production and/or marketing activities (Dunning, 1977). These advantages are based on the possession and use of particular intangible assets, such as patents, trademarks, management skills (Caves, 1996), and brand names, as well as skilled labor, knowledge of technology, and efficient production processes (Wernerfelt, 1984). These advantages enable the firm to achieve high levels of technical or price efficiency (Caves, 1996). These intangible advantages of MNCs are geographically mobile and can be transferred internally within the MNCs across national borders. These are the areas in which foreign firms have advantages that are superior to those of local firms, enabling them to compensate for the lack of access to local resources and for the additional costs associated with doing business abroad, thereby allowing them to compete successfully in foreign countries (Hymer, 1960/1976). FSAs are important factors in determining the performance of MNCs (Dunning, 1981), as they affect not only a firm’s upstream activities (e.g., Dunning, 1981), such as the level of FDI in the subsidiaries (Rugman, 2005), but also the downstream activities (Rugman \& Sukpanich, 2006). A firm’s unique resources and capabilities can therefore generate competitive advantages, leading to sustainable superior returns (Barney, 1991). Foreign firms are generally superior to domestic firms in R\&D, production and marketing, as they may possess significantly better strategic capabilities relative to their local domestic competitors with respect to internal dimensions, with a significantly higher ability to adapt to competition in foreign markets in the context of external dimensions (Fiegenbaum, Hart, \& Schendel, 1996). In addition, foreign firms may be better able to manage rapid change than their local counterparts (Lavie \& Fiegenbaum, 2000). In the Chinese context, most foreign firms have a clear competitive advantage over local firms in capabilities such as technology, know-how and innovation, branding, financing, IT and value-chain creation (Williamson \& Zeng, 2004).

The development of FSAs by Chinese firms reflects their improvements in productivity relative to foreign firms in China. Rugman and Li (2007) have argued that while Chinese firms have improved their FSAs over time, they still lag significantly behind their foreign competitors in productivity. A number of factors may have contributed to these competitive disadvantages. First, Chinese firms in many industries and business sectors still operate under strong protection from various levels of government in China (Nolan, 2004), although operating in an open market 
is one of the most effective ways for local firms to develop FSAs (Caves, 1996). In recent years, the Chinese government has taken various measures to build national innovative capacity by focusing on a number of key industries such as information technology, high-end manufacturing, biotechnology, etc., so as to establish national champions in these industries (Hu \& Mathews, 2008). However, the mechanism adopted for achieving these ambitions continues to be centralized government support and protection rather than intense competition and rivalry in the domestic market (Hemphill \& White III, 2013). Such protection reduces the incentive for local firms to develop much-needed FSAs (Rugman \& Li, 2007). Second, 'uncertainty' is still perceived by many practitioners and researchers to be one of the significant features of the Chinese business environment (Teagarden, 2010). Under an uncertain environment with a weak institutional infrastructure (e.g., weak intellectual property protection), especially when firms confront greater uncertainty in the transitional environment, it is safer for firms to mimic or model their own behavior and practices on leading multinational firms, especially in the areas of technology upgrade and the adoption of management know-how (Deng, 2009; Hall et al., 2011). In addition, the relative technological advantages of foreign firms may be a barrier for local Chinese firms to patent or patent around. Third, the existence of a large technological gap may also induce Chinese firms to devote more attention to learning and less to innovation ( $\mathrm{Li}, 2011)$. However, the learning and transfer of knowledge and technology from foreign firms to local Chinese firms have become even more difficult in recent years. Some recent empirical studies (e.g., Li, 2011) have suggested that the presence of foreign firms has no detectable impact on the indigenous innovation of domestic firms (Li, 2011). The developed country firms investing in China over the last decade mostly take the form of wholly-owned subsidiaries rather than joint ventures (Peng, 2006); therefore, the knowledge and technology spillover effect from foreign firms to local Chinese firms has been significantly weakened (Sun et al., 2012). In addition, foreign patents mostly belong to companies located in Japan, the USA, South Korea, and developed European countries that have subsidiaries in China. The inflow of technology that goes hand in hand with FDI is then modified and transformed to adapt to local market needs. Thus, original and basic foreign R\&D activities in China are comparatively low (Tang and Hussler, 2011).

International acquisitions can also be an effective way to acquire knowledge in the form of technological capabilities, management, and strategic skills (Cui, Jiang, \& Stening, 2011). This 
strategy may, however, not apply to Chinese firms that are at an early stage of internationalization because of their broad lack of experience with innovation may make it difficult for them to recognize and absorb all of the potential value of the acquired company. The lack of this experience may delay the knowledge transfer and integration process. They often have a limited ability to effectively assimilate acquired knowledge and technology so as to improve their capabilities (He \& Mu, 2012). Even large Chinese firms still suffer from a lack of internal managerial capabilities to adequately integrate foreign acquisitions and build dynamic capabilities (Williamson \& Raman, 2011). This competitive disadvantage in management as compared with foreign firms (especially MNCs) will take at least a decade to remedy (Rugman $\& \mathrm{Li}, 2007)$. Thus, the superior FSAs of foreign firms operating in China helps them to eliminate the negative impact of the LOF that could arise from a lack of local knowledge and skills, thereby contributing to a positive effect on their overall performance in the country. We therefore propose the following hypothesis:

Hypothesis 1: Foreign firms outperform local Chinese firms in terms of firm-specific advantages, and these foreign firms' competitive advantages eliminate the negative effect of the liability of foreignness, with a positive effect on their relative performance.

\section{Multi-Nationality Advantages}

While firm-specific advantages are essential for a firm's competitiveness (Dunning, 1993), multi-nationality is a specific characteristic of multinational firms. Multi-nationality advantages arise directly from undertaking cross-border business activities under a common governance structure (Nachum, 2003). These advantages are associated with the coordination of multiple geographically dispersed value-added activities, including the ability to spread common and central overhead over many different nations (which is especially critical in R\&D-intensive industries that require $R \& D$ to be amortized over more than a few markets); the facilitation of greater learning from international experience (Kobrin, 1991); access to cheaper and valuable resources in foreign countries (which could include cheaper labor, better technology, or any country-specific resource) (Porter, 1990); the ability to monitor global rivals, markets, and other profit opportunities; and better cross-subsidization, price discrimination, and arbitrage potential as a result of a greater geographic scope (Contractor, Kundu, \& Hsu, 2003). Hence, the greater 
the degree of multi-nationality of a given MNC, the better its management regime will be (Teece, 1986). This stronger management regime leads to improved firm performance, especially when the firm's degree of multi-nationality is based on FDI (Morck \& Yeung, 1992). By virtue of their activities in multiple markets, MNCs are often also exposed to a wealth of empirical and anecdotal information regarding economic and political trends (Luo, 2003). As such, they have a distinct competitive advantage over local firms, provided they are able to effectively synthesize information, communicate, make sound decisions and adapt their strategies accordingly (Goitom \& Clemens, 2006). Therefore, an important strength of foreign MNCs over most local firms is their globally coordinated competitive activities (Nachum, 2003). Such activities help to amplify the competitive advantages of MNCs in specific foreign markets, further enhancing their global competitive position (Ma, 1999).

Over the past three decades, the competitiveness of the Chinese domestic industries has been enhanced to a certain extent through government-funded technology upgrades and political support associated with industry restructuring. As a result, quite a number of Chinese firms, especially large state-owned enterprises and non-state-owned group companies, have been able to leverage home country-specific advantages based on low costs and economies of scale in the context of firm-specific advantages in market and technological adaptability (Zhan, 1995). However, although there are now many Chinese firms that are large in terms of asset size or market capitalization, very few are truly multinational. Rather than aggressively going abroad to exploit existing ownership advantages, Chinese firms engaged in FDI abroad primarily do so to acquire complementary resources (Buckley, Clegg, Cross, Liu, Voss, \& Zheng, 2007; Williamson \& Raman, 2011). Chinese firms are generally challenged by the regulatory and business cultures in advanced economies and require support from internationally experienced advisors. Significant differences exist between regulatory, socio-cultural, and business practices in emerging and advanced economies. Operating in developed country markets requires the managers of many emerging country firms to bridge language and cultural divides, comply with unfamiliar and sophisticated regulatory procedures, processes and standards, acquire local market knowledge, manage local staff, negotiate with organized labor and other stakeholders, achieve higher quality and safety product and service standards, adhere to different tax and accounting rules and develop appropriate communications and public relations strategies (Sun et al., 2013). 
Therefore, the FDI activities of Chinese firms are targeted at a limited number of host locations that can serve their investment purposes. It may take large Chinese firms decades to accumulate these much-needed capabilities and eventually become truly multinational (Rugman \& Li, 2007).

Foreign firms conducting FDI in China are, by definition, participants in international networks, whereas the vast majority of Chinese firms only operate within mainland China and do not share the multi-nationality advantages that most foreign firms enjoy. Furthermore, the theory of the MNC suggests that MNCs possess advantages that arise from their favorable access to resources within their home countries (Nachum, 1999). MNCs of developed and/or advanced countries, having operated in developed and sophisticated home markets, have built skill bases that confer clear advantages over firms in most other countries (Erramilli, Agarwal, \& Kim, 1997). The set of competitive advantages of an MNC thus includes competitive advantages that are partly derived from the resources of the home country as well as those resulting from the strategic activities of the firm in the global marketplace (Dunning, 1977). MNCs benefit from national differences in market structure, product life cycles, and environmental resources through utilizing their monopolistic advantages (Hymer, 1960/1976). They are likely to achieve higher performance than local domestic firms when expanding internationally (Morck \& Yeung, 1991). Foreign firms in China therefore benefit from considerably more of the advantages associated with multi-nationality than their Chinese-owned counterparts. These advantages help foreign firms to eliminate the negative impact of the LOF that could arise from a lack of local knowledge and skills in China while also exerting a positive effect on performance. We therefore propose the following hypothesis:

Hypothesis 2: Foreign firms outperform local Chinese firms in terms of multinationalitiy advantages, and these foreign firms' competitive advantages eliminate the overall negative effect of the liability of foreignness for foreign firms by providing a positive effect on the foreign firms' relative performance.

\section{Location (China)-Based Advantages}

Local indigenous firms have the general advantage of better information about their country regarding its economy, language, laws, and policies. They enjoy favorable access to the 
resources of their home country relative to foreign firms due to favorable treatment by the government, consumers and suppliers (Hymer, 1960/1976). This theoretical paradigm has been the fundamental underlying assumption for the development of theories regarding MNCs (Dunning, 1977). Hence, we can expect the indigenous firms to possess more of the advantages that arise from utilizing the resources of their home countries. Firms are also the product of the locations in which they operate, and effective firms will seek to build on competencies forged in their home country (Erramilli, Agarwal, \& Kim, 1997). The case for expecting either homebased or location-based advantages to confer advantages to local firms over foreign firms is particularly strong when the country concerned is advantageous in a location-related way in comparison with the home country of the foreign investing firm (Nachum, 2003). Local firms are established in the context of appreciable location-specific advantages and proceed in a fashion that showcases those advantages (Erramilli, Agarwal, \& Kim, 1997). Local firms are usually well versed in domestic customs and priorities and have the ability to utilize this local knowledge to their advantage (Vachani, 1990). This advantage is further emphasized in high-context cultures such as China, where guanxi relationships pervade all levels of the enterprise and government, and outsiders can find it difficult to gain traction (Deng, 2003).

Guanxi is an intricate aspect of the Chinese business culture that has significantly challenged the foreign firms operating in China. China has a business culture based on strong family connections secured in the guanxi networks (Hutchings \& Weir, 2006). The Chinese term guanxi refers to the concept of drawing on connections to secure favors in personal and/or business relationships (Luo, 1997), and the core idea of guanxi involves relationships between or among individuals creating obligations for the continued exchange of favors (Dunfee \& Warrant, 2001). The relationship between guanxi and firm performance for both local Chinese and foreign firms in China has been well documented in the literature (e.g., Hutchings \& Weir, 2006). Guanxi based business variables have a significant and positive impact on firm performance and venture success in China (Luo, 1997; Yang, 1998), and no business in China can go far unless it has extensive guanxi (Campbell, 1987; Shenkar, 1990), as guanxi is a necessary factor contributing to business success in China (Tsang, 1998). Guanxi has been pervasive in the Chinese business world for a few hundred years (Luo, 1997), and as a Chinese social tradition, guanxi is still deeply rooted in the Chinese culture (Varma, Budhwar, \& Pichler, 2011), which makes it rather 
difficult and challenging for foreign firms and their managers from other cultures to adjust to the Chinese business environment (Bjorkman \& Liu, 1999; Ting \& Worm, 2001).

To summarize, China is a complex society by virtue of its deeply embedded and multilayered cultural heritage, its long history, its diverse social and political features, and its vast geographical scale, which encompasses common national characteristics alongside strong local identities, traditions and dialects ( $\mathrm{Li} \& \mathrm{Li}$, 1999). This complexity could be a critical challenge for most outsiders operating in China, but it could also be a competitive advantage for local firms that are deeply rooted in the environment. Such location-related assets provide local firms with some strong competitive advantages that foreign firms do not have (Nachum, 2003). We can thus expect local Chinese firms to outperform foreign firms in China in terms of location-based advantages. This expectation implies that foreign firms are likely to experience increased costs, reduced operating efficiency and profitability, and diminished competitiveness relative to indigenous Chinese firms. We therefore propose the following hypothesis:

Hypothesis 3: Local Chinese firms outperform foreign firms in terms of location based advantages, and these local Chinese firms' competitive advantages accentuate the liability of foreignness for foreign firms, with a negative effect on the foreign firms' relative performance.

\section{Relative Importance of Various Advantages}

Although local firms are often well placed to assess and respond to economic trends within their own country, such firms occupy a potentially risky position depending on the economic characteristics of that country. MNCs, however, are able to reduce risk by effectively engaging in international portfolio investment. It is the firm's ability to balance this portfolio that will determine risks and returns and that will ultimately prove to be either a competitive advantage or a weakness. MNCs from developed countries have a significant competitive advantage in this regard, outperforming their developing country counterparts, and the most profitable enterprises may prove to be those developed country MNCs that have operations in developing countries (Collins, 1990). A multinational firm can reduce the negative impact of its liability of foreignness compared to domestic competitors by learning about the host-country environment through the accumulation of investment experience there (Johanson \& Vahlne, 1977) and by 
gaining capabilities that are relevant to the host country (Chang, 1995). This process of learning about the host-country environment may further strengthen some of the FSAs of MNCs because the relevance and importance of firm-specific advantages are also host-location specific (Dunning, 1988). The host country becomes especially important in studies addressing FDI, because the different configuration of host-country factor endowments, demand conditions and competition (Dunning, 1995) and institutional development (Hermelo and Vassolo, 2010) can either strengthen the firm or render it redundant.

In the Chinese context, the development of its institutions has moved to a much more advanced level compared to the level that existed before the country opened its door for foreign investment over thirty years ago (Child and Tse, 2001). Consistent with the logic of Hermelo and Vassolo (2010), as institutions develop, the resource-based advantages of firms, such as FSAs and MNAs, become more important for competitive success than the institutional-based advantages that result from access to LBAs. Therefore, in the Chinese context, FSAs and MNAs may provide more explanatory power for the relative performance of foreign firms vis-à-vis local firms than location-based advantages. In other words, the FSAs and MNAs that foreign firms possess can help them to offset the negative impacts of competitive disadvantages (i.e., LOF). We therefore propose the following hypothesis:

Hypothesis 4: The negative effect of foreign firms' China location-based disadvantages (i.e., liability of foreignness) on their relative performance as compared with local Chinese firms will be offset by the positive effect of the foreign firms' superior firm-specific and multinationality advantages over local Chinese firms.

\section{Methods}

\section{Sample and Data Collection}

Large Chinese firms are on the front line in competing with foreign entrants and are usually the primary Chinese competitors targeted by foreign firms. We initially identified the largest one thousand purely local firms (i.e., Chinese firms with no foreign ownership) from the ORBIS Database published by Bureau van Dijk Electronic Publishing in 2007. This database contains information on over 300,000 Chinese firms. However, of the largest one thousand firms, 851 were contactable by telephone. We then further identified 149 local firms making up a final 
sample of one thousand largest pure local Chinese firms that are contactable as the sample for this survey. The senior executives (e.g., CEOs, general managers, marketing directors/managers) of those firms are the best placed to provide information about the nature of competition and tensions between their firm and foreign firms in mainland China. We therefore directed our request for information to these senior executives. A structured questionnaire was used to obtain the perceptions of senior executives of local Chinese firms regarding the strength of the three types of advantages and the performance of both the local firms and their primary foreign competitors. The questionnaire was translated into Chinese by two bilinguals and was pre-tested before the survey commenced. We required that the respondents be senior executives who had sufficient knowledge about the competitive positions of their own company and their main foreign competitors in China. First addressing their own (local Chinese) firms, the respondents were asked to first evaluate the level of advancement in terms of each of the independent variable indicators (the various advantages) and the level of firm performance as measured by the dependent variable metrics. They were then asked to evaluate the same set of variable indicators for their primary foreign competitors competing in the same market segment or product market. Following a common practice in Delphi studies (Sniezek, 1989), the respondents were also asked to estimate their self-perceived level of "expertise" on a five-point scale (' 1 ' being lowest and ' 5 ' being highest) in relation to their subjective evaluation of each of the independent and dependent variable indicators. These "expertise" ratings were included as weights to reflect the fact that in assessing the various advantages of both foreign and local firms, it was likely that some respondents would not feel as competent to provide estimates of the level of advantages of their foreign competitors as they would for those of their own firm. A total of 935 questionnaires were delivered, primarily via facsimile (but complemented by postal mail), of which 136 were completed and returned after telephone follow-up over a period of two months early in 2007. In addition, 65 questionnaires were delivered in person to firms in the sample frame via networking connections, 63 of which were completed and returned to us. In total, 199 firms returned questionnaires. A screening of the returned questionnaires found that 185 were usable, constituting a response rate of $18.5 \%$. The primary foreign rivals identified by the respondents are from 17 economies: 70.1\% from developed countries, 25.6\% firms from newly industrialized economies, and $4.3 \%$ from developing countries. 


\section{Dependent Variable Indicators}

Following Nachum's (2003) study, we used the ratio of the performance of foreign firms relative to the performance of their local Chinese counterparts as the dependent variable to measure the LOF. We then created a single compound measure for each of the dependent and independent variable constructs by summing the weighted scores of the individual variable indicators for each construct. The performance of both the local and the foreign firms was measured using five subjective assessment questions on a five-point scale (' 1 ' being poor and ' 5 ' being outstanding). The five firm-performance indicators ( $\alpha=0.931$ for Chinese firms; $\alpha=0.892$ for foreign firms) covered profitability, market share, sales growth, competitive position (Aulakh, Kotabe, \& Teegen, 2000; Fey \& Bjorkman, 2001), and the quality of products/services (Fey \& Bjorkman, 2001). These measures have been widely used to measure the performance of both emerging and foreign firms in prior studies. The measurement of firm performance may be particularly problematic in emerging economies. Financial reporting problems emanate from a variety of causes, including lack of standards, differing regimes and systems, lack of reporting enforcement, unreported activity involving bartering, and substantial inflation and devaluation of local currencies. These types of problems apply to all facets of the accounting process and to both listed and non-listed companies in emerging economies (Hoskisson, Eden, Lau \& Wright, 2000). China is no exception. As Devonshire-Ellis and Zhang (2011) note, it has been consistently shown that accounts are incorrectly prepared for reasons ranging from incompetence (low levels of accounting education) to fraud. More importantly, due to the significant differences between China and developed countries in terms of the institutional setting, the violation of generally accepted accounting principles in financial reporting by publically traded firms, especially those that are state controlled, is very common in mainland China (Noronha \& Zeng, 2008). The firms conduct earnings management practices ranging from legitimate accounting decisions to engaging in financial reporting fraud (Chen \& Yuan, 2004). Therefore, just as subjective measures of firm performance relative to competitors are frequently more reliable and valid when studying emerging businesses (Chandler \& Hanks, 1993), so are they likely to be more suitable for measuring firm performance in emerging countries. Precedents exist for using perceptual measures of performance (e.g., Fey \& Bjorkman, 2001), and the subjective managerial assessment approach has been widely used in research studies focused on China (e.g., Luo, 1997). 


\section{Independent Variable Indicators}

The independent variable indicators were adopted from earlier research studies (see below). In comparison with most prior studies on the LOF, we incorporate a relatively larger set of variables with the aim of capturing as comprehensively as possible the various advantages that a local or foreign firm may possess; this step was necessary to address the shortcomings of using a limited number of indicative items, as suggested by prior studies (e.g., Nachum, 2003). All of the items for each independent variable were measured on a five-point scale (' 1 ' being very low and '5' being very high). Firm-specific advantage was measured using nine items ( $\alpha=0.800$ for Chinese firms; $\alpha=0.816$ for foreign firms), including firm size, financial strength, managerial skills (Nachum, 2003), marketing ability (Morck \& Yeung, 1992), technology (Wernerfelt, 1984), research and development intensity (Morck \& Yeung, 1992), knowledge acquisition and value creation (Rugman \& Sukpanich, 2006), brand name, innovation ability and success (Caves, 1996). Multi-nationality advantage was measured using five items ( $\alpha=0.708$ for local firms; $\alpha$ $=0.767$ for foreign firms), including the intensity of international activity (Nachum, 2003), the knowledge of global markets (Lemi, 2006), access to global financial resources (Collins, 1990; Lemi, 2006), access to global human resources (Ger, 1999), and global synergy (Meyer, 2004). Location (China)-based advantage was measured using six items ( $\alpha=0.800$ for local firms; $\alpha=$ 0.860 for foreign firms), including access to local information, the product/service preferences of local customers, reliance on local resources (Nachum, 2003), connection to the local market (Fiegenbaum, Lavie, \& Shoham, 2004), ability to respond to the local market (Sally, 2007), and the level of local government support (Derkinderen, 1982).

\section{Control Variables}

A set of control variables that has commonly been used in prior studies (e.g., Luo \& Park, 2001; Nachum, 2003) was included in our model tests. Given the substantial differences in market conditions between industrial and nonindustrial sectors, we controlled for industry effects using a dummy variable for industry sector (IS). The service sector was coded as ' 0 ' and the manufacturing sector was coded as ' 1 '. Cultural distance (CD) affects the method of foreign market entry and subsequent performance through its effect on the development of rentgenerating capabilities (Luo \& Park, 2001). Utilizing the measures in Hofstede (2001), we followed Slangen (2006) and calculated a relative cultural distance index that estimates the 
composite deviation of a foreign firm's home-country culture from Chinese culture in terms of four cultural dimensions: uncertainty avoidance, individualism, power distance, and masculinity. The length of operation (LO) in China (that is, age measured as the number of years the firm has operated in China) reflects the level of experience, which may influence the path and the extent of competitive success under conditions of uncertainty. The entry mode (EM) was coded as a dummy variable (' 0 ' being a joint venture or $\mathrm{JV}$, and ' 1 ' being a wholly-owned subsidiary or WOS).

\section{Model Specification}

To test the hypotheses, a model was constructed to examine the effects of the three types of advantage for both foreign and Chinese firms on their performance metrics.

$$
\begin{aligned}
P_{f} / P_{l c}= & \beta_{0^{+}} \beta_{1} F_{-} F S A+\beta_{2} F_{-} M N A+\beta_{3} F_{-} L B A+\beta_{4} L_{-} F S A+\beta_{5} L_{-} M N A+\beta_{6} L_{-} L B A \\
& +I S+C D+L O+E M+e
\end{aligned}
$$

where, $P_{f}=$ performance of foreign firm; $P_{l c}=$ performance of local Chinese firm; $F \_F S A=$ firm-specific advantages of foreign firm; $F_{-} M N A=$ multi-nationality advantages of foreign firm; $F \_L B A=$ location (China)-based advantages of foreign firm; $L \_F S A=$ firm-specific advantages of Chinese firm; $L \_M N A=$ multi-nationality advantages of Chinese firm; $L \_L B A=$ location (China)-based advantages of Chinese firm; $I S$ = industrial sector; $L O=$ length of operation of the foreign firm in China; $E M=$ entry mode of the foreign firm in China; and $C D=$ cultural distance.

\section{Results and Analysis}

To generate a weighted score for each dependent and independent variable indicator, we multiplied the original raw score of each indicator by the self-assessed score for expertise in evaluating the variable indicator; the result was then divided by the sum of scores for all of the observations ( $\mathrm{n}=185)$. The subsequent steps in the statistical analyses used the weighted scores, with the exception of the scale reliability test and Harman's one-factor test to detect the presence of common method variance (CMV). Table 1 presents the operational measures, descriptive statistics, and correlations between independent variables, as well as the control variables. None of the correlation coefficients is greater than 0.6. A correlation coefficient above 0.6 is considered to be somewhat high (Churchill, 1991). We also further checked the variance 
inflation factor (VIF) when performing the regression analysis procedures. The VIF for the full models (Model 3 and Model 6) are reported in Table 3.

\section{INSERT Table 1 ABOUT HERE}

Table 2 presents the results of the independent-sample T-tests that aimed to examine the relative strengths of the various advantages exhibited by local Chinese and foreign firms and their performance. The results are consistent with the relative strengths of the advantages presented in hypotheses 1,2 , and 3. The only exception is the mean score for the indicator variable related to the product and service preferences of local customers. The results also clearly show that foreign firms outperform local Chinese firms.

\section{INSERT Table 2 ABOUT HERE}

The hierarchical regression analysis results are presented in Table 3. The results show that the $F$ statistics that were generated in all of the models are all significant at the .001 level, and the model fit improves substantially as the testing procedure moves from model 1 (the control variable model) to model 3 (the main effect model), as measured by changes in the adjusted Rsquare values and $F$ statistics. As we move from models 1 to 3 , the beta coefficients are all impacted correspondingly. As shown in Table 3, the signs of the beta coefficients for all of the variables are in the hypothesized direction (refer to the estimates for Model 3). Five variables, including F_FSA, F_MNA, F_LBA, L_FSA, and L_LBA were found to be statistically significant, while L_MNA appears to be insignificant in the model. By comparing the beta coefficients and assessing the three types of advantage for foreign and local Chinese firms, respectively, we found that the relative power in explaining the contributions of the various advantages to the relative performance of foreign firms over local Chinese firms for each pair of corresponding advantages (e.g., L_FSA vs. F_FSA) is consistent with hypotheses 1, 2, and 3. The beta coefficients of F_FSA $\left(\beta_{1}=0.265, \mathrm{p}<.001\right)$ and F_MNA $\left(\beta_{2}=0.143, \mathrm{p}<.01\right)$ are significantly higher than those of L_FSA $\left(\beta_{4}=-0.165, \mathrm{P}<.01\right)$ and L_MNA $\left(\beta_{5}=-0.070, \mathrm{P}>.1\right)$, whereas the beta coefficient of L_LBA $\left(\beta_{6}=-0.288, \mathrm{p}<.001\right)$ is greater than that of F_LBA 
$\left(\beta_{3}=0.100, \mathrm{p}<.05\right)$ and is the greatest among all of the variables. While the full model (Model 3) showed a significant improvement over Model 2 through the inclusion of the three types of advantage for local Chinese firms, the beta coefficients for the three respective advantages of foreign firms decreased significantly, suggesting that all three types of local Chinese firm advantage exerted a negative impact on the foreign firms' relative performance metrics; in particular, the L_FSA and L_LBA were statistically significant, and the L_LBA appears to have the greatest impact on the relative performance of foreign firms over local firms. Therefore, the results suggest that foreign firms can outperform local Chinese firms in terms of both firmspecific and multi-nationality advantages, and these competitive advantages of foreign firms may eliminate the impact of the LOF on their performance in China. In contrast, we conclude that the local Chinese firms outperform their foreign counterparts in location-based advantages, and these competitive advantages of the local firms may contribute to the LOF for foreign firms in China, with a negative impact on the foreign firms' performance. Hypotheses 1, 2, and 3 are supported. These results are supported by the totality of findings revealed from many recent research studies on technology development and the innovation capabilities of local firms (e.g., Hemphill \& White III, 2012; Yi et al., 2013; Zhang, 2013), the learning and spill-over effect of inward FDI in China (e.g., He \& Mu, 2012; Hoon \& Zhang, 2011; Tang \& Hussler, 2011), the knowledge and technology absorptive capacity of Chinese firms (e.g., $\mathrm{Hu} \& \mathrm{Mu}, 2012$; Li, 2011), the competitive advantages and disadvantages of emerging Chinese MNEs (e.g., Prange, 2012; Sun et al., 2013; Wu et al., 2011), and developed country MNEs' innovation in emerging markets (Nonis \& Relyea, 2012). It is suggested that both the Chinese and the foreign firms operating in the Chinese market have been taking measures to address their respective disadvantages and further enhance their strengths (Nonis \& Relyea, 2012), while significant gaps in various advantages such as knowledge, technologies, and innovation capacity between the local Chinese and foreign firms effectively remain (Sun et al., 2012; Sun et al., 2013; Yi et al., 2013).

The combined explanatory power of firm-specific and multi-nationality advantages in the context of foreign firms (as measured by the beta coefficients; $\beta_{1+} \beta_{2}=0.508$ ) is significantly greater than that of the firm-specific and location-based advantages of the local firms $\left(\beta_{4}+\beta_{6}=-\right.$ 0.453), suggesting that the negative impact of the LOF on foreign firms may be significantly offset by the positive impact of the joint power of their firm-specific and multi-nationality advantages. Hypothesis 4 is therefore supported. The improved location-based advantages of 
foreign firms may contribute to the elimination of the LOF and its negative impact on foreign firm performance. Model 3 confirms that the revealed impact on the performance of foreign firms relative to local firms may be greater in the service sector $(\beta=-0.140, \mathrm{p}<.01)$. In addition, it is evident that foreign firms are securing location-based advantages that may help them to gradually overcome their competitive (location-based) disadvantages, thereby eliminating the LOF.

INSERT Table 3 ABOUT HERE

\section{Results Validation}

In the absence of an additional sample, we performed validity tests before and after the modeltesting procedures. Prior to model testing, we tested for non-response bias in our analysis sample of 185 firms. Independent sample t-tests were performed to compare the early and later response groups on the values of all of the variables, and no significant difference was found between the early and late response groups. This result suggests that non-response bias did not exist in our sample. We also split the sample into two sub-samples (sub-sample 1 included the first $50 \%$ of the received usable questionnaires, and sub-sample 2 included the second $50 \%$ of the received usable questionnaires) and, in addition, we randomly extracted a sample that was approximately $50 \%$ of the full sample (SPSS generated a random sample of 100 cases). We then performed a stepwise regression analysis for the main effect models using the overall sample $(n=185)$, subsample 1 ( $n=93)$, sub-sample $2(n=92)$, and the random sample $(n=100)$. Comparison of the overall model fit indicates a high level of similarity for the results with respect to the $R^{2}$, the adjusted $R^{2}$, and the standard error of the estimates. The regression coefficient and beta coefficient estimates across the different samples appear to be highly similar, indicating that the sample represents the population.

Studies that investigate perceptions using surveys run the risk of common method variance. Following Podsakoff and Organ's (1986) study, we used Harman's one-factor test to measure the presence of the common method effect. The principal component analysis with Varimax rotation revealed the presence of four and six distinct factors (rather than a single factor) with an eigenvalue greater than 1.0 for the datasets of the foreign and local Chinese firms, respectively. The four factors (measuring the advantages of the foreign firms) together accounted for $60.7 \%$ of 
the total variance; the first (largest) factor did not account for a majority of the variance (22.17\%). The six factors (measuring the advantages of the local Chinese firms) together accounted for $69.3 \%$ of the total variance; the first (largest) factor did not account for a majority of the variance (13.9\%). Therefore, we found no evidence of common method variance in the data.

\section{Discussions and Conclusions}

The study has provided an extension to the LOF framework of Nachum (2003), which argued that the LOF is a function of the relative strength of three types of advantage (firm-specific, multinationality, and location-based) held by foreign firms. We extended this framework by incorporating the strength of local firms, proposing that the relative performance of foreign firms over local firms is a function of the interplay between the relative strength of the foreign and local firms that compete in the same product market. This study is one of the first studies to empirically examine the existence of an LOF in China. In this context, the advantages of both foreign and local firms appear to have negative impacts on each other. However, the negative impacts of the local firms' advantages on the foreign firms' relative performance are weaker than the negative impacts from the foreign firms' advantages on local Chinese firms. This result suggests that the impact of the LOF on foreign firms’ performance may be offset by the foreign firms' superior competitive advantages over local Chinese firms. In other words, an LOF may exist, but it is insignificant for foreign firms. These findings carry important practical implications. As Luo (2007) has noted, foreign firms in China are turning themselves from foreign investors into strategic insiders. Now may be the time for them to consider transforming themselves further to become strategic allies of local Chinese firms. Foreign firms could make this transformation by forming or strengthening vertical and/or inter-organizational linkages with relatively competitive Chinese firms to combine the strength of, or take advantage of, the complementary resources and capabilities of both local Chinese firms and foreign firms. Aside from helping them compete successfully with other competitors in China, this transformation would help the foreign firms achieve greater corporate-level synergy among subsidiaries globally and would provide competitive advantages in the global marketplace, especially in the markets of other transitional economies. 
Many foreign firms have learned how to build their own guanxi networks (Tsang, 1998) and operate successfully in emerging markets such as China (Nonis \& Relyea, 2012). These firms have transformed themselves from foreign investors into strategic insiders in China (Luo, 2007). These firms' overall strategy has become even more aggressive, shifting from adapting to local market conditions to innovating and developing emerging markets and creating the opportunity not only to compete more effectively but also to lead and dominate the competition in emerging markets and protect their home markets in their home countries (Nonis \& Relyea, 2012). Consequently, it is suspected that this transformation leads to an even greater gap in the competitive advantages between the local and foreign firms operating in the Chinese market. Therefore, in relation to local firms, as foreign firms catch up with the location (in this case, China)-based advantages such as local market knowledge, the competitive location-based advantages of local firms may not be sustained for long. Local firms should thus avoid reliance on these types of advantage, especially those created by the institutional support provided by the home-country government (in China, by national, provincial, city, and even county-level authorities) and should seek to become more innovative to strengthen and further develop their firm-specific and multinationality advantages. This challenge is non-trivial- learning and developing firm-specific and multinationality advantages by local firms is likely to be a much slower process than the acquisition of particular host-country, location-based advantages by foreign firms. This study has two limitations that future research should seek to address. First, while this study has broken ground in examining the LOF in China, it did so only from the perspective of local firms. Second, this study has provided a snapshot that does not capture all of the complexities of the actual situation. Thus, aside from incorporating the perspectives of foreign firms, future research should seek to build a longitudinal data set to examine how the LOF evolves and how the competitive position of both foreign and Chinese firms changes over time in this huge and ever-changing market.

\section{Acknowledgment}

A previous version of this article was presented at the 2009 Academy of Management annual meeting and 2009 Strategic Management Society International Conference. We are grateful for insightful comments and suggestions received from Professor Lilach Nachum, Professor Lorraine Eden, and Professor Anoop Modhak. The revision of the article also benefited greatly 
from the comments and suggestions of two anonymous reviewers and Professor Mary Teagarden, the editor of the Thunderbird International Business Review.

\section{References}

Aulakh, S. P., Kotabe, M., \& Teegen H. (2000). Export strategies and performance of firms from emerging economies: evidence from Brazil, Chile, and Mexico. Academy of Management Journal, 43(3), 342-361.

Björkman, I., \& Lu, Y. (1999). The management of human resources in Chinese-Western joint ventures. Journal of World Business, 34, 304-324.

Barney, J. (1991). Firm resources and sustained competitive advantages. Journal of Management, 17(1), 99-120.

Buckley, P. J., Clegg, L. J., Cross, R. A., Liu, X., Voss, H., \& Zheng, P. (2007). The determinants of Chinese outward foreign direct investment. Journal of International Business Studies, 38(4), 499-518.

Campbell, N. (1987). Experiences of western companies in China. Euro-Asia Business Review, July, 35-38.

Caves, R. E. (1996). Multinational Enterprises and Economic Analysis. Cambridge University Press: New York.

Chandler, G. N., \& Hanks, S. H. (1993). Measuring the performance of emerging businesses: A validation study. Journal of Business Venturing, 8(5), 391-408.

Chang, S. J. (1995). International expansion strategy of Japanese firms: Capability building through sequential entry. Academy of Management Journal, 38(2), 383-407.

Chang, S. J., van Witteloostuijn, A., \& Eden, L. (2010). From the editors: common method variance in international business research. Journal of International Business Studies, 41(2), 178-184.

Chang, S. J., \& Xu, D. (2008). Spillovers and competition among foreign and local firms in China. Strategic Management Journal, 29(5), 495-518.

Chartier, C. (1998). China: economic reforms and WTO Accession. Thunderbird International Business Review, 40(3), 257-277.

Chen, C. W., \& Yuan, H. Q. (2004) Earnings management and capital resources allocation: evidence from China's accounting-based regulation of rights issues. The Accounting Review, 79(3), 645-665.

Churchill, G. A. (1991). Marketing Research: Methodological Foundation, $5^{\text {th }}$ ed. The Dryden Press: Chicago.

Collins, J. M. (1990). A market performance comparison of U.S. firms active in domestic, developed and developing countries. Journal of International Business Studies, 21(2), 271287.

Contractor, J. F., Kundu, K. S., \& Hsu, C. C. (2003). A three-stage theory of international expansion: the link between multinationality and performance in the service sector. Journal of International Business Studies, 34(1), 5-18.

Cui, L., Jiang, F., \& Stening, W. B. (2011). How do Chinese MNCs choose FDI entry modes? Firm resources, industry conditions, and institutional forces. Thunderbird International Business Review, 53(4), 483-500. 
Deng, P. (2003). Foreign investment by multinationals from emerging countries: The case of China. Journal of Leadership and Organizational Studies, 10(2), 113-124.

Deng, P. (2009). Why do Chinese firms tend to acquire strategic assets in international expansion? Journal of World Business, 44, 74-84.

Derkinderen, F. G. J. (1982). Transnational business latitude in developing countries. Management International Review, 22(4), 55-65.

Devonshire-Ellis, C., \& Zhang, J. (2011). Analyzing Chinese Financial Reporting. China Briefing: Magazine and Daily News Service February 7, 2011. (www.china-briefing.com)

Dunfee, T. W., \& Warrant, D. E. (2001). Is guanxi ethical? a normative analysis of doing business in China. Journal of Business Ethics, 32, 191-204.

Dunning, J. H. (1977). Trade, location of economic activity and the MNE: A search for an eclectic approach. In The International Allocation of Economic Activity, Ohlin B, Hesselborn P, Wijkman M (eds). Holmes and Meier: New York.

Dunning, J. H. (1981). International Production and the Multinational Enterprise. George Allen \& Unwin: London.

Dunning, J. H. (1988). The eclectic paradigm of international production: A restatement and some possible extensions. Journal of International Business Studies, 19(1), 9-31.

Dunning, J. H. (1993). Multinational Enterprises and the Global Economy. Addison-Wesley: Wokingham.

Dunning, J. H. (1995). Reappraising the eclectic paradigm in an age of alliance capitalism. Journal of International Business Studies, 26(3), 461-492.

Elliot, G., Jiang, F., Redding, G., \& Stening, W. B. 2010. The Chinese business environment in a decade: A report on Delphi study. Asian Business and Management, 9(4): 459-480.

Erramilli, M. K., Agarwal, S., Kim, S. S. (1997). Are firm-specific advantages location-specific too? Journal of International Business Studies, 28(4), 735-757.

Fey. C. F., \& Bjorkman, I. (2001). The effect of human resource management practices on MNC subsidiary performance in Russia. Journal of International Business Studies, 32(1), 59-75.

Fiegenbaum, A., Hart, S., \& Schendel, D. (1996). Strategic reference point theory. Strategic Management Journal, 17(3), 219-235.

Fiegenbaum, A., Lavie, D., \& Shoham, A. (2004). The competitive positioning of foreign MNEs in domestic markets: Theoretical extensions and evidence from the Israeli market. Management International Review, 44(3), 261-284.

Fligstein, N., \& Zhang, J. (2011). A new agenda for research on the trajectory of Chinese capitalism. Management and Organization Review, 7(1), 39-62.

Ger, G. (1999). Localizing in the global village: Local firms competing in global markets. California Management Review, 41(4), 64-83.

Goitom, T., \& Clemens, L. (2006). A classification of export marketing problems of small and medium sized manufacturing firms in developing countries. International Journal of Emerging Markets, 1(3), 262-281.

Haley, G. T., Haley, U. C. V., \& Tan, C. T. (2004). The Chinese Tao of Business: The Logic of Successful Business Strategy. John Wiley \& Sons: Singapore.

Hall, J., Matos, S., Silvestre, B., \& Martin, M. (2011). Managing technological and social uncertainties of innovation: The evolution of Brazilian energy and agriculture. Technological Forecasting \& Social Change, 72(2), 213-236. 
He, X., \& Mu, Q. (2012). How Chinese firms learn technology from transnational corporations: A comparison of the telecommunication and automobile industries. Journal of Asian Economics, 23, 270-287.

Hemphill, T. A., \& White III, G. O. (2013). China's national champions: The evolution of a national industrial policy - or a new era of economic protectionism? Thunderbird International Business Review, 55(2), 193-212.

Hermelo, F. D., \& Vassolo, R. (2010). Institutional development and hypercompetition in emerging economies. Strategic Management Journal, 31(13), 1457-1473.

Hofstede, G. (2001). Culture's Consequences: Comparing Values, Behaviors, Institutions, and Organizations across Nations. Sage Publications: London.

Hoskisson, E. R., Eden, L., Lau, C. M., \& Wright, M. (2000). Strategy in emerging economies. Academy of Management Journal, 43(3), 249-267.

Hu, M. C., \& Mathews, J. A. (2008). China's national innovative capacity. Research Policy, 37(9), 1465-1479.

Hu, X., \& Mu, Q. (2012). How Chinese firms learn technology from transnational corporations: A comparison of the telecommunication and automobile industries. Journal of Asian Economics, 23(3), 270-287.

Huang, Y. (2008). Capitalism with Chinese Characteristics: Entrepreneurship and the State. Cambridge University Press: New York.

Hutchings, K., \& Weir, D. (2006). Guanxi and Wasta: A comparison. Thunderbird International Business Review, 48(1), 141-156.

Hymer, S. H. (1960/1976). International Operations of National Firms: A Study of Direct Foreign Investment. MIT Press: Cambridge, MA.

Jiang, F. 2005. Driving forces of international pharmaceutical firms' FDI into China. Journal of Business Strategies, 22(1): 21-39.

Jiang, F., \& Stening, W. B. (2013). Do indigenous firms incur a liability of localness when operating in their home market? The case of China. Journal of World Business, 48(4): 478489.

Johanson, J., \& Vahlne, J. E. (1977). The internationalization process of the firm-A model of knowledge development and increasing market commitments. Journal of International Business Studies, 8(1), 23-32.

Kobrin, S. J. (1991). An empirical analysis of the determinants of global integration. Strategic Management Journal, 12, 17-37.

Kostova, T., \& Zaheer, S. (1999). Organizational legitimacy under conditions of complexity: The case of the multinational enterprise. Academy of Management Review, 24(1), 64-81.

Kronborg, D., \& Thomsen, S. (2009). Foreign ownership and long-term survival. Strategic Management Journal, 30(2), 207-219.

Lavie, D., \& Fiegenbaum, A. (2000). The strategic reaction of domestic firms to foreign MNC dominance: The Israeli experience. Long Range Planning, 33(5), 651-672.

Lemi, A. (2006). Determinants of sales destinations of U.S. multinational firms' affiliates in developing countries. The International Trade Journal, 20(3), 263-305.

Li, F., \& Li, J. (1999). Foreign Investment in China. Houndmills: Macmillan Press.

$\mathrm{Li}, \mathrm{X}$. (2011). Sources of external technology, absorptive capacity, and innovation capability in Chinese state-owned high-tech enterprises. World Development, 39(7), 1240-1248.

Lin, N. (2011). Capitalism in China: A centrally managed capitalism and its future. Management and Organization Review, 7 (1), 63-96. 
Luo, Y. (1997). Guanxi and performance of foreign-invested enterprises in China: an empirical inquiry. Management International Review, 37(1), 51-70.

Luo, Y. (1997). Partner selection and venturing success: The case of joint ventures with firms in the People's Republic of China. Organization Science, 8(6), 648-662.

Luo, Y. (2003). Market-seeking MNEs in an emerging market: How parent-subsidiary links shape overseas success. Journal of International Business Studies, 34(3), 290-309.

Luo, Y. (2007). From foreign investors to strategic insiders: Shifting parameters, prescriptions and paradigms for MNCs in China. Journal of World Business, 42(1), 14-34.

Luo, Y., \& Park, S. H. (2001). Strategic alignment and performance of market- seeking MNCs in China. Strategic Management Journal, 22(2), 141-55.

Ma, H. (1999). Creation and preemption for competitive advantage. Management Decision, 37(30), 259-266.

Meyer, K. E. (2004). Perspectives on multinational enterprises in emerging economies. Journal of International Business Studies, 35(4), 259-276.

Mezias, J. M. (2002). Identifying liability of foreignness and strategies to minimize their effects: The case of labour lawsuit judgments in the United States. Strategic Management Journal, 23(3), 229-244.

Miller, S., \& Parkhe, A. (2002). Is there a liability of foreignness in global banking? An empirical test of banks’ X-efficiency. Strategic Management Journal, 23(1), 55-75.

Morck, R., \& Yeung, B. (1991). Why investors value multinationality. Journal of Business, 64(2), 165-187.

Morck, R., \& Yeung, B. (1992). Internalization: an event study test. Journal of International Economics, 33(1-2), 41-56.

Nachum, L. (1999). Does nationality of ownership make any difference and, if so, under what circumstances? Professional service MNEs in global competition. Journal of International Management, 9(1), 1-32.

Nachum, L. (2003). Liability of foreignness in global competition? Financial service affiliates in the city of London. Strategic Management Journal, 24(12), 1187-1208.

Nachum, L. (2010). When is foreignness an asset or a liability? Explaining the performance differential between foreign and local firms. Journal of Management, 36(3), 714-739.

Nolan, P. (2004). China at the Crossroads. Polity Press: Cambridge.

Nonis, S. A., \& Relyea, C. (2012). Business innovations from emerging market countries into developed countries: Implications for multinationals from developed countries. Thunderbird International Business Review, 53(3), 291-298.

Noronaha, C., \& Zeng, Y. (2008). Earnings management in China: an exploratory study. Managerial Auditing Journal, 23(4), 367-385.

North, D. C. (1990), Institutions, Institutional Change, and Economic Performance, Cambridge: Cambridge University Press.

Peng, M. (2006). Forethought global strategy: Making M\&A fly in China. Harvard Business Review, March, 1-2.

Podsakoff, P. M., \& Organ, D. W. (1986). Self-reports in organizational research: Problems and prospects. Journal of Management, 12(2), 531-544.

Porter, M. E. (1990). The Competitive Advantage of Nations. The Free Press: New York.

Prange, C. (2012). Ambidextrous internationalization strategies: The case of Chinese firms entering the world market. Organizational Dynamics, 41, 245-253.

Rugman, A. M. (2005). The Regional Multinationals. Cambridge University Press: Cambridge. 
Rugman, A., \& Li, J. (2007). Will China's multinationals succeed globally or regionally? European Management Journal, 25(5), 333-343.

Rugman, A. M., \& Sukpabich, N. (2006). Firm-specific advantages- intra-regional-sales-andperformance of multinational enterprises. The International Trade Journal, 20(3), 355-382.

Sally, S. (2007). Globalization and performance in the new millennium: A look at firms from developed and developing nations. Journal of American Academy of Business. Cambridge, 10(2), 51-60.

Shenkar, O. (1990). International joint ventures' problems in China: risks and remedies. Long Range Planning, 23(3), 82-90.

Slangen, A. H. L. (2006). National cultural distance and initial foreign acquisition performance: the moderating effect of integration. Journal of World Business, 41, 161-170.

Sniezek, J. A. (1989). An examination of group process in judgmental forecasting. International Journal of Forecasting, 5(2), 171-178.

Sun, S. L., Peng, M. W., Ren, B., \& Yan, D. (2012). A comparative ownership advantage framework for cross-border M\&As: The rise of Chinese and Indian MNEs. Journal of World Business, 47(1), 4-16.

Sun, S. L., Zhang, Y., \& Chen, A. (2013). The challenges of Chinese outward investment in developed countries: The case of CITIC Pacific's Sino iron project in Australia. Thunderbird International Business Review, 55(3), 313-322.

Tang, M., \& Hussler, C. (2011). Betting on indigenous innovation or replying on FDI: The Chinese strategy for catching-up. Technology in Society, 33, 23-35.

Teagarden, M. (2010). Dynamic emerging markets. Thunderbird International Business Review, 52(5), 353-354.

Teece, D. J. (1977). Technology transfer by multinational firms: The resource cost of transferring technological know-how. Economic Journal, 87, 242-261.

Tsang, E. W. K. (1998). Can guanxi be a sustainable competitive advantage for doing business in China? Academy of Management Executive, 12(2), 64-73.

Tung, R. L., \& Worm, V. (2001). Network capitalism: The role of human resources in penetrating the China market. International Journal of Human Resource Management, 12, 517-534.

UNCTAD (United Nations Conference on Trade and Development). (2005-2010). World Investment Report. United Nations Publications: New York and Geneva.

Vachani, S. (1990). Strategic responses of multinationals to competition from developingcountry cottage firms. International Marketing Review, 7(3), 31-47.

Varma, A., Budhwar, P., \& Pichler, S. (2011). Chinese host country nationals' willingness to help expatriates: the role of social categorization. Thunderbird International Business Review, 53 (3), 353-364.

Walder, A. G. (1996). China’s Transitional Economy. Oxford University Press: England:

Wernerfelt, B. (1984). A resource-based view of the firm. Strategic Management Journal, 5(2), 171-180.

White, R. E., Hoskisson, R. E., Yiu, D. W., \& Bruton, G. D. (2008). Employment and market innovation in Chinese business group affiliated firms: The role of group control systems. Management Organization Reviewer. 4(2): 225-256. 
Wu, F., Hoon., L. S., \& Zhang, Y. (2011). Dos and don'ts for Chinese companies investing in the United States: Lessons from Huawei and Haier. Thunderbird International Business Review, 53(4), 501-515.

Williamson, P., \& Raman, A. P. (2011). How China reset its global acquisition agenda. Harvard Business Review, 89 (4), 109-114.

Williamson, P., \& Zeng, M. (2004). Strategies for competing in a changed China. MIT Sloan Management Review, 45(4), 85-91.

$\mathrm{Xu}, \mathrm{C}$. (2011). The fundamental institutions of China's reforms and development. Journal of Economic Literature, 49: 1076-1151.

Yang, J. Z. (1998). Key success factors of multinational firms in China. Thunderbird International Business Review, 40(6), 633-668.

Yi, J., Wang, C., \& Kafouros, M. (2013). The effects of innovative capabilities on exporting: Do institutional forces matter? International Business Review, 22, 392-406.

Zaheer, S. (1995). Overcoming the liability of foreignness. Academy of Management Journal, 38(2), 341-363.

Zaheer, S., \& Mosakowski, E. (1997). The dynamic of the liability of foreignness: A global study of survey. Strategic Management Journal, 18(6), 439-464.

Zhan, J. X. (1995). Transnationalization of outward investment: The case of Chinese firms. Transnational Corporations, 4(3), 61-93.

Zhang, C. (2013). The inner circle of technology innovation: A case study of two Chinese firms. Technological Forecasting \& Social Change, dx.doi.org/10.1016/j.techfore.2013.06.005 
FIGURE 1 Advantages Determining Competitive Strength of Local Chinese and Foreign Firms

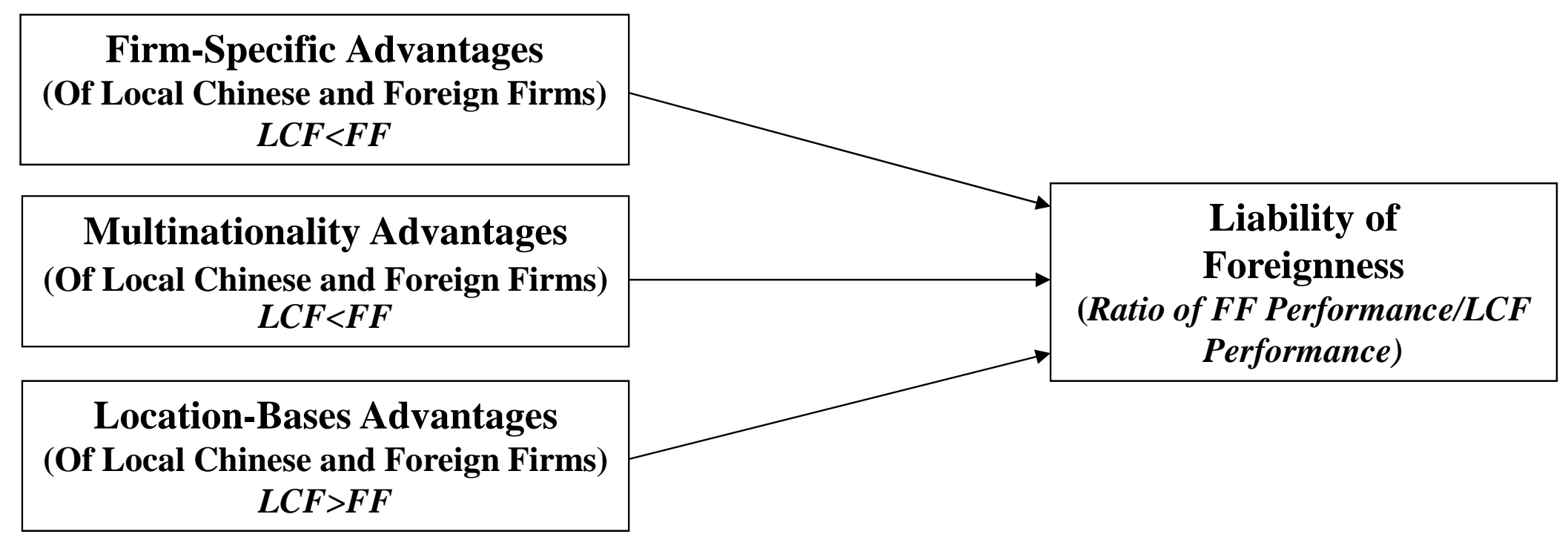

Note: LCF- Local Chinese firm; FF - Foreign firm 
TABLE 1 Independent Variables, Descriptive Statistics and Correlations ( $\mathrm{n}=185)$

\begin{tabular}{|c|c|c|c|c|c|c|c|c|c|c|c|c|c|c|}
\hline Constructs & Operational measures & $\begin{array}{l}\text { Weighted } \\
\text { Mean }\end{array}$ & Mean & S.D. & 1 & 2 & 3 & 4 & 5 & 6 & 7 & 8 & 9 & 10 \\
\hline $\begin{array}{l}\text { 1. Firm-specific advantage } \\
\text { of local Chinese firms }\end{array}$ & Compound variable & 23.721 & 23.584 & 2.351 & 1.000 & & & & & & & & & \\
\hline $\begin{array}{l}\text { 2. Multi-nationality advantage } \\
\text { of local Chinese firms }\end{array}$ & Compound variable & 8.337 & 8.276 & 1.288 & $.416^{* * *}$ & 1.000 & & & & & & & & \\
\hline $\begin{array}{l}\text { 3. Location-based advantage } \\
\text { of local Chinese firms }\end{array}$ & Compound variable & 23.559 & 25.114 & 2.173 & $.567^{* * *}$ & $.489^{* * *}$ & 1.000 & & & & & & & \\
\hline $\begin{array}{l}\text { 4. Firm-specific advantage } \\
\text { of foreign firms }\end{array}$ & Compound variable & 38.945 & 38.649 & 2.805 & $-.444^{* * *}$ & $-.470^{* * *}$ & $-.484^{* * *}$ & 1.000 & & & & & & \\
\hline $\begin{array}{l}\text { 5. Multi-nationality advantage } \\
\text { of foreign firms }\end{array}$ & Compound variable & 21.845 & 21.676 & 1.643 & $-.439^{* * *}$ & $-.354^{* * *}$ & $-.398^{* * *}$ & $.591^{* *}$ & 1.000 & & & & & \\
\hline $\begin{array}{l}\text { 6. Location-based advantage } \\
\text { of foreign firms }\end{array}$ & Compound variable & 20.921 & 20.260 & 3.298 & $-.250^{* *}$ & $-.266^{* * *}$ & $-.341^{* * *}$ & $.470^{* *}$ & $.520^{* * *}$ & 1.000 & & & & \\
\hline 7. Industrial sector & $\begin{array}{l}\text { Dummy } \\
\text { (Manufacturing, service) }\end{array}$ & & 0.640 & 0.482 & $.216^{* *}$ & ** $.329^{*}$ & $.438^{* * *}$ & $-.420^{* *}$ & $-.402^{* * *}$ & $-.377^{* *}$ & 1.000 & & & \\
\hline 8. Cultural distance & Index & & 2.422 & 1.114 & -.031 & $-.247^{* * *}$ & $-.249^{* *}$ & $.167^{*}$ & $.227^{* *}$ & .010 & $-.142 \dagger$ & 1.000 & & \\
\hline 9. Length of Operation & $\begin{array}{l}\text { No. of years operating in } \\
\text { China }\end{array}$ & & 14.314 & 3.607 & -.064 & -.131 & -.021 & .136 & -.045 & -.090 & .106 & .040 & 1.000 & \\
\hline 10. Entry mode & $\begin{array}{l}\text { Dummy (Joint venture, } \\
\text { wholly owned subsidiary) }\end{array}$ & & 0.730 & 0.445 & -.017 & -.017 & -.094 & .057 & .020 & .050 & -.028 & .093 & -.096 & 1.000 \\
\hline
\end{tabular}

$\dagger \mathrm{p}<.10 ; * \mathrm{p}<.05 ; * * \mathrm{p}<.01 ; * * * \mathrm{p}<.001 ;$ (2-tailed).

Non-parametric Spearman Rank correlations are reported where nominal data are used. 
TABLE 2 Comparison of Competitive Advantages between Foreign and Local Chinese Firms

\begin{tabular}{|c|c|c|c|c|c|c|c|}
\hline \multirow{2}{*}{ Variable constructs and indicators } & \multicolumn{2}{|c|}{ Local firms } & \multicolumn{2}{|c|}{ Foreign firms } & \multirow{2}{*}{$\begin{array}{l}\text { t-value } \\
\text { (Sig.) }\end{array}$} & \multicolumn{2}{|c|}{ Weighted Mean } \\
\hline & Mean & S.D. & Mean & S.D. & & Local Firm & Foreign Firm \\
\hline \multicolumn{8}{|l|}{ Firm-specific advantages } \\
\hline Brand name & 2.800 & 0.452 & 4.714 & 0.465 & $-40.125^{* * *}$ & 2.817 & 4.756 \\
\hline Technology advancement & 1.924 & 0.303 & 3.768 & 0.484 & $-43.924 * * *$ & 1.926 & 3.785 \\
\hline R\&D intensity & 2.043 & 0.327 & 4.584 & 0.556 & $-53.554 * * *$ & 2.053 & 4.627 \\
\hline Knowledge acquisition and value creation & 2.103 & 0.304 & 4.670 & 0.471 & $-62.237 * * *$ & 2.111 & 4.709 \\
\hline Financial strength & 2.557 & 0.498 & 4.411 & 0.504 & $-35.580 * * *$ & 2.572 & 4.452 \\
\hline Firm size & 3.541 & 0.551 & 4.211 & 0.546 & $-11.752 * * *$ & 3.561 & 4.247 \\
\hline Marketing skills & 3.124 & 0.431 & 4.114 & 0.408 & $-22.679 * * *$ & 3.142 & 4.140 \\
\hline Management skills & 2.368 & 0.484 & 4.032 & 0.465 & $-33.754 * * *$ & 2.393 & 4.055 \\
\hline Innovation ability and success & 3.124 & 0.362 & 4.146 & 0.495 & $-22.659 * * *$ & 3.146 & 4.174 \\
\hline \multicolumn{8}{|l|}{ Multi-nationality advantages } \\
\hline Intensity of international business activity & 2.097 & 0.298 & 4.595 & 0.503 & $-58.121^{* * *}$ & 2.115 & 4.643 \\
\hline Knowledge of global markets & 1.935 & 0.247 & 4.092 & 0.426 & $-59.544 * * *$ & 1.944 & 4.126 \\
\hline Access to global financial resources & 1.719 & 0.451 & 4.741 & 0.440 & $-65.280 * * *$ & 1.724 & 4.777 \\
\hline Access to global HR resources & 1.368 & 0.484 & 4.357 & 0.503 & $-58.309 * * *$ & 1.395 & 4.393 \\
\hline Global synergy & 1.157 & 0.365 & 3.892 & 0.403 & $-68.487 * * *$ & 1.159 & 3.906 \\
\hline \multicolumn{8}{|l|}{ Location (China)-based advantages } \\
\hline Access to local information & 4.589 & 0.493 & 3.243 & 0.715 & $21.075 * * *$ & 4.611 & 3.264 \\
\hline Connection to local markets & 4.768 & 0.424 & 3.395 & 0.753 & $21.626^{* * *}$ & 4.327 & 3.430 \\
\hline Ability to respond to local market/customer needs & 4.297 & 0.470 & 3.941 & 0.739 & $5.543 * * *$ & 4.327 & 3.970 \\
\hline Product and service preferences of local customers & 3.092 & 0.549 & 3.924 & 0.741 & $-12.282 * * *$ & 3.104 & 3.968 \\
\hline Reliance on local resources & 4.459 & 0.580 & 3.400 & 0.627 & $16.864 * * *$ & 4.484 & 3.451 \\
\hline Level of local government support & 3.908 & 0.539 & 2.357 & 0.717 & $23.536 * * *$ & 3.929 & 2.838 \\
\hline \multicolumn{8}{|l|}{ Firm performance } \\
\hline Profitability & 3.360 & 0.816 & 4.687 & 0.729 & $-11.996 * * *$ & 3.371 & 4.375 \\
\hline Market share & 2.708 & 1.114 & 4.335 & 0.742 & $-16.394 * * *$ & 2.719 & 4.383 \\
\hline Sales growth & 4.011 & 0.759 & 4.319 & 0.950 & $-3.786^{* * *}$ & 4.026 & 4.373 \\
\hline Product and service quality & 3.600 & 0.892 & 4.687 & 0.729 & $-12.370^{* * *}$ & 3.618 & 4.721 \\
\hline Competitive position & 2.978 & 0.642 & 4.119 & 0.889 & $-13.865 * * *$ & 2.948 & 4.124 \\
\hline
\end{tabular}

$\dagger \mathrm{p}<.10 ;{ }^{*} \mathrm{p}<.05 ;{ }^{* *} \mathrm{p}<.01 ;{ }^{* * *} \mathrm{p}<.001 ;$ (2-tailed). 
TABLE 3 Impact on the Relative Firm Performance of Foreign Firms over Local Chinese Firms

\begin{tabular}{|c|c|c|c|c|}
\hline & Model 1 & Model 2 & Model 3 & VIF \\
\hline \multicolumn{5}{|l|}{ Control variables } \\
\hline Industrial sector & $-0.524 * * *$ & $-0.221 * * *$ & $-0.140 * *$ & 1.468 \\
\hline Cultural distance & $0.142 *$ & 0.069 & 0.030 & 1.205 \\
\hline Length of operation (Foreign firm) & $0.149 *$ & $0.084 \dagger$ & $0.067 \dagger$ & 1.101 \\
\hline Entry mode (Foreign firm) & 0.004 & 0.000 & -0.016 & 1.027 \\
\hline \multicolumn{5}{|l|}{ Independent variables } \\
\hline Firm-specific advantage of foreign firms & & $0.415^{* * *}$ & $0.265^{* * *}$ & 2.047 \\
\hline Multi-nationality advantage of foreign firms & & $0.214^{* *}$ & $0.143^{* *}$ & 2.004 \\
\hline Location-based advantage of foreign firms & & $0.123^{*}$ & $0.100 *$ & 1.584 \\
\hline Firm-specific advantage of local Chinese firms & & & $-0.165 * *$ & 1.791 \\
\hline Multi-nationality advantage of local Chinese firms & & & -0.070 & 1.549 \\
\hline Location-based advantage of local Chinese firms & & & $-0.288 * * *$ & 2.028 \\
\hline \multicolumn{5}{|l|}{ Model fit } \\
\hline $\mathrm{N}$ & 185 & 185 & 185 & \\
\hline $\mathrm{R}^{2}$ & 0.324 & 0.632 & 0.756 & \\
\hline Adj- $R^{2}$ & 0.309 & 0.618 & 0.742 & \\
\hline F value & $21.532 * * *$ & $43.499 * * *$ & $53.979 * * *$ & \\
\hline
\end{tabular}

All coefficients are standardized

$\uparrow \mathrm{p}<.10 ;{ }^{*} \mathrm{p}<.05 ;{ }^{* *} \mathrm{p}<.01 ; * * * \mathrm{p}<.001$; (2-tailed). 